This is an electronic reprint of the original article. This reprint may differ from the original in pagination and typographic detail.

Author(s): Tervo, Hannu; Haapanen, Mika

Title: $\quad$ Opportunity- and Necessity-Driven Self-Employment Among Older People in Finland

Year: $\quad 2017$

Version:

Please cite the original version:

Tervo, H., \& Haapanen, M. (2017). Opportunity- and Necessity-Driven SelfEmployment Among Older People in Finland. In I. Aaltio, A. J. Mills, \& J. H. Mills (Eds.), Ageing, Organisations and Management : Constructive Discourses and Critical Perspectives (pp. 255-276). Palgrave Macmillan. https://doi.org/10.1007/978-3-31958813-1_12

All material supplied via JYX is protected by copyright and other intellectual property rights, and duplication or sale of all or part of any of the repository collections is not permitted, except that material may be duplicated by you for your research use or educational purposes in electronic or print form. You must obtain permission for any other use. Electronic or print copies may not be offered, whether for sale or otherwise to anyone who is not an authorised user. 


\title{
Opportunity- and necessity-driven self-employment among older people in Finland
}

\author{
Hannu Tervo \\ Professor \\ Jyväskylä University School of Business and Economics, Finland \\ P.O. Box 35, FI-40014 University of Jyvaskyla \\ p +358503062174 / fax +35814617194 / e-mail hannu.t.tervo@jyu.fi

\section{Mika Haapanen} \\ Senior Researcher \\ Jyväskylä University School of Business and Economics, Finland \\ P.O. Box 35, FI-40014 University of Jyvaskyla \\ p +358405767800 / fax +358 14617194 / e-mail mika.p.haapanen@jyu.fi
}

\begin{abstract}
:
To date, few empirical studies have attempted to highlight the impact of the socio-economic characteristics of older entrepreneurs on whether they are driven by necessity or opportunity. Tervo and Haapanen contribute to the economics of ageing by showing that opportunity- and necessitydriven senior entrepreneurs differ in terms of socio-economic characteristics. This chapter utilizes a longitudinal data set from Finland. Individuals aged 55-70 entering self-employment are grouped in terms of pull and push motivations. Profiles of entrepreneurs are developed using personal, family and environmental characteristics. The results show that opportunity-driven older self-employed workers are more likely to be highly educated males, whereas necessity-driven older self-employed workers are often less educated females and individuals who live in rural areas.
\end{abstract}

Keywords: self-employment; senior entrepreneurship; push and pull motivations; opportunity; necessity 


\section{INTRODUCTION}

In many developed countries, the workforce is aging but is still needed for productive work. Entrepreneurship is an opportunity for many older individuals as either a career option or a form of partial retirement. Self-employment allows workers the freedom to adjust their working hours, which is an advantage for many older full-time workers. However, older individuals may also be pushed into self-employment in the absence of alternatives. While pull motives are considered positive, push factors often have negative connotations (Kirkwood 2009; Dawson and Henley 2012). Interestingly, sociological theories suggest that low-wage workers are pushed into entrepreneurship, whereas high-wage workers are pulled into entrepreneurship by attractive opportunities (Clain 2000). The push-pull dichotomy is perhaps over-simplistic (Williams 2007) ${ }^{1}$; however, this dichotomy is useful in categorizing background motives, especially due to the lack of comprehensive theory on the issue of necessity and opportunity entrepreneurship.

In the literature, the existing research on the necessity-push vs. opportunity-pull debate has not provided conclusive answers. Do market pull, higher expected earnings, the promise of independence, flexibility and opportunities, and the fulfilment of lifelong dreams dominate, or are individuals pushed into entrepreneurship because of reduced income or simply because nothing else is available? In his review, Parker (2004) concluded that overall, the econometric evidence from cross-sectional studies supports the 'prosperity-pull hypothesis', while time-series and panel data evidence mostly support the 'recession-push' hypothesis (see also Parker 2009). However, recent cross-sectional evidence based mostly on the analysis of transitions into entrepreneurship from unemployment lends more support to the role of push factors (e.g., Earle and Sakova 2000; Moore and Mueller 2002; Ritsilä and Tervo 2002; Tervo 2006; Niefert 2010; Brünjes and Diez 2013).

\footnotetext{
${ }^{1}$ As the result of many studies based on the Global Entrepreneurship Monitor (GEM) database, the push-pull terminology has partly given way to necessity- and opportunity-driven entrepreneurship (cf. Giacomin et al., 2011).
} 
The results of Global Entrepreneurship Monitor (GEM) research show that necessity as a primary entrepreneurial motive is low in Finland, whereas a relatively large share of individuals also possesses the motives of both opportunity and necessity (Heinonen et al. 2006). Similarly, Giacomin et al. (2011) showed that there are diverse necessity and opportunity entrepreneurial dynamics and that these two dynamics can combine within the same individual. Their results suggested that young people in particular can be driven in their entrepreneurial motivation by both necessity and opportunity dynamics: they can simultaneously search for social recognition and profit and a need for independence. In contrast, older jobseekers were found to be driven solely by a 'get out of unemployment' entrepreneurial dynamic and, thus, by necessity entrepreneurship (Giacomin et al. 2011).

Related to age, van Praag and van Opheim (1995) found that the opportunity to become selfemployed was significantly higher for older than for younger Americans; however, older workers were less willing to become self-employed than younger workers. Thus, age may have different effects on the willingness and opportunity to become self-employed. Empirical results have shown both positive (Reynolds et al. 2002) and negative relationships (Block and Wagner 2010; Robichaud et al. 2010; Giacomin et al. 2011) between age and opportunity entrepreneurship, while in Bergman and Stenberg (2007), age did not have an impact on the probability of necessity entrepreneurship. Thus, further research is needed to fully understand the relationship between age and opportunity vs. necessity entrepreneurship.

Why would someone on the verge of retirement start a business? Transitions to self-employment later life may be either a career option or a step toward retirement, known as "bridge employment." Bridge employment is part-time or short-duration employment that occurs in the gap between career employment and complete retirement (Quinn 2002; Ruhm 1990). To date, few empirical studies 
have attempted to highlight the impact of socio-economic characteristics of older entrepreneurs on their positioning in terms of necessity or opportunity entrepreneurship (see, however, Block and Wagner 2010; Kautonen et al. 2011; Heimonen 2013). By interviewing nascent entrepreneurs aged between 50 and 64 years, Heimonen (2013) concluded that both pull and push factors simultaneously influence becoming entrepreneur in Finland. According to these results, the building blocks of entrepreneurship in older age are life and work experience, longitudinally developed know-how, personal networks, flexibility, and current personal life situations. On the contrary, small pensions and the threat of job losing one's job or unemployment benefits were on the push side.

Many of the earlier studies are based on small samples and interviews. Utilizing large register-based data on all Finns, the aim of this explorative study is to obtain an understanding what motivates older individuals to switch into self-employment in Finland. For this purpose, profiles of necessity and opportunity entrepreneurs in terms of personal, family and environmental characteristics are developed based on empirical analyses. This chapter aspires to contribute to the economics of ageing by showing that opportunity and necessity senior entrepreneurship differ in terms of socioeconomic characteristics.

\section{PUSH AND PULL MOTIVATIONS AMONG OLDER PEOPLE}

Levesque and Minniti (2006) presented a theoretical model in which aging individuals have an incentive to reallocate more of their time to waged labour and less to starting a new firm. According to this model, the willingness to invest time in starting new firms among older people declines because the opportunity costs of starting a new firm increase. If an individual is employed in waged work, (s)he receives income at the time in which (s)he performs that activity. If an individual allocates time to starting a new firm, instead, (s)he does not receive income instantaneously but 
rather receives a stream of future returns. Therefore, in the model by Levesque and Minniti (2006), an age effect reduces the relative return to entrepreneurship as individuals become older.

However, age may also increase interest in entering self-employment for various other reasons, such as the human and financial capital requirements of entrepreneurship, which are often unavailable to younger workers, or better social and business networks, which older people typically have (Parker 2009). The age dimension is also explicitly present, for example, in the social development model by Gibb and Ritchie (1982) and in Dyer's (1994) model of entrepreneurial careers. These models focus on the entrepreneurial career process and the antecedents influencing the process and on distinguishing those with entrepreneurial intentions from those with no current entrepreneurial intentions. In the social development model by Gibb and Ritchie (1982), the influences are dependent on the stage of life when one becomes an entrepreneur. Dyer's (1994) model includes the entrepreneurial career from entry to exit.

These models advocate the view of entrepreneurship as a process (see also Ronstadt 1984; Low and MacMillan 1988; Davidsson et al. 2001) and suggest that becoming an entrepreneur is a real option for older workers. A positive life-cycle effect - reflecting a general increase in the self-employment rate with age - was found, for example, by Bönte et al. (2007), Leung and Robinson (1998) and Quinn and Kozy (1996). Improved health, finances, and quality of life, as well as various innovative arrangements, enable individuals to continue working at later ages, even after having retired (Zhang 2008). 


\section{Hypothesis Development}

Senior entrepreneurs may have diverse motivations for starting a new business. One way to divide entrepreneurial motivations among senior entrepreneurs is to apply the distinction between push factors and pull factors, although the motivations do not inevitably exclude one another (Eijdenberg and Masurel 2013). Both motivations might apply for many seniors, which should be taken into account in the analysis.

Many individuals entering self-employment might have previous experience in self-employment. This is evidently true among habitual or serial entrepreneurs who continuously come up with new ideas and start new businesses. Serial entrepreneurship accounts for a significant portion of entrepreneurial activity. Earlier results have also shown that most individuals entering selfemployment in later life have prior self-employment experience, suggesting that entrepreneurship at later ages is often habitual (Tervo 2014). With regard to push and pull motivations, however, the effect of prior experience is inconclusive.

\section{Hypothesis 1: Previous experience in self-employment}

Prior self-employment experience does not differentiate between push and pull motivations of entrepreneurship at older ages.

Women represent a minority of the self-employed workforce in all developed countries (Parker 2009). Women may be somewhat more likely than men to choose bridge employment because they

usually exit the workforce earlier in their careers and, accordingly, have smaller pensions. Therefore, push motivations may predominate among older women. 
A long-established hypothesis is that education increases an individual's probability of entrepreneurship because it enhances her/his human capital (Rees and Shah 1986; Parker 2009). An opposite hypothesis argues that the higher earnings capacity that arises due to a higher education level decreases the probability of entering self-employment (Le 1999; Parker 2009). Several results from Finland suggest that individuals with a lower level of education have a higher probability of entrepreneurship (Johansson 2000; Uusitalo 2001; Niittykangas and Tervo 2005; Tervo and Haapanen 2011). This evidence gives support to the latter hypothesis. However, an exception is the case of older workers, for whom higher education has been found to enhance entrepreneurship in Finland (Tervo 2014). We may assume that this finding is specifically related to opportunity-driven entrepreneurship. In addition to the level of education, the main educational orientation can be important. Pull motivations are assumed to be prevalent among seniors who have a commercial, technical, or medical education (Karoly and Zissimopoulos 2004).

\section{Hypothesis 2: Individual characteristics}

(a) The probability of opportunity-driven self-employment is higher among older men than older women.

(b) The probability of opportunity-driven self-employment at older ages increases with as the education level increases.

(c) The probability of opportunity-driven self-employment at older ages increases with business, technical, and medical education.

Family relations may also differentiate senior entrepreneurs with diverse motivations. Karoly and Zissimopoulos (2004) suggest that self-employment decisions may be best viewed from the perspective of the household rather than the individual. In their study about self-employed individuals age 51 and above in the United States in 1998, Karoly and Zissimopoulos (2004) showed that 27 percent of self-employed workers had spouses who were also self-employed, which 
was a higher rate than that for the spouses of waged workers. Family support may help selfemployed individuals run their business. Family characteristics may also constrain the choice between self-employment and paid employment. It can be expected that pull motivations become stronger if a senior is married, has a spouse who is working, and especially if the spouse is an entrepreneur him/herself (Blanchflower and Oswald 1990; Parker 2009).

\section{Hypothesis 3: Family relations}

(a) The probability of opportunity-driven self-employment increases if a senior is married.

(b) The probability of opportunity-driven self-employment at older ages increases if a spouse is working and if (s)he is an entrepreneur.

Different regions provide varying opportunities for entrepreneurship (Reynolds et al. 1994; Tervo 2007; Parker 2009). Rural areas are typically characterized by weaker conditions of employment and low demand, while urban areas provide more possibilities for entrepreneurship. Less educated seniors in small, dispersed labour markets may be pushed into self-employment if they see no other realistic employment options in the region (Moore and Mueller 2002). Similarly, high unemployment in a region may push seniors into self-employment (Ritsilä and Tervo 2002)

\section{Hypothesis 4: Regional environment}

(a) The probability of opportunity-driven self-employment at older ages is higher in urban areas than in rural areas.

(b) The probability of opportunity-driven self-employment increases if a senior lives in a low unemployment area. 


\section{DATA AND METHODS}

The data are from Finland and are based on various registers kept by Statistics Finland, including Longitudinal Population Census File, Longitudinal Employment Statistics File and Register of Completed Degrees. The data comprise all individuals who reside permanently in Finland. The individual-level panel data are transformed and pooled into a sample of individuals aged 55-70 years who transitioned into non-agricultural self-employment during the 2002-2006 period. This period was a time of economic growth. The data include 8,703 transitions to self-employment, of which $4,749(54.6 \%)$ were from wage work and 3,954 (45.4\%) were from non-employment. Approximately 63 percent of entrants to self-employment were males.

The data contain individual-, family-, and regional-level information. The individual-level factors comprise variables indicating whether the individuals had previous self-employment experience since 1987, whether they were wageworkers or non-employed before the transition to selfemployment, their gender, their financial situation in taxable income and taxable property, and their education level and field. Family characteristics describe whether they were married or cohabiting prior to self-employment, whether their spouses were entrepreneurs and/or non-employed and their spouse's taxable property. The environmental variables we utilize are a dummy variable indicating whether they lived in an urban or a rural municipality prior to entry to self-employment and a variable measuring the unemployment level at the local labour market area, using NUTS-4 regional classification.

In the statistical analysis, those who transitioned into self-employment $(n=8,703)$ are grouped based on their labour market activity and financial situation one year before the transition using a statistical multivariate technique, cluster analysis, and three variables available in the data: wageworker/non-employed, taxable income, and taxable property. Thus, the clustering is grounded 
solely on "cold" facts; other types of push and pull motivations cannot be recorded in an analysis based on register data. There are many clustering algorithms of which the k-medians cluster analysis is used due to the skewed distribution of the income and property variables. This partitionclustering method breaks the observations into a distinct number of overlapping groups, the number of which here is three. Each observation is assigned to the group in which the median is closest; new group medians are then determined based on that categorization. These steps continue until no observations change the groups. The similarity measure used is the Euclidean distance.

The next step in the analysis is to evaluate how various personal, family, and environmental factors vary among the entrepreneurs belonging to each one of the clusters. Can we find variables that discriminate between opportunity- and necessity-driven senior entrepreneurs? In this analysis, a one-way analysis of variance (ANOVA) is first used to test for the significant differences between means. After this preliminary overview, a multinomial logit regression is conducted to analyse further the effect of each variable on the probability that a self-employed worker belongs to one of the clusters. In the analysis, both the estimated coefficients and marginal effects are reported.

\section{RESULTS}

In this study, individuals who started a new business later in life are first grouped according to their recognizable push and pull motivations. Then, the features of these groups are analysed. Thus, to obtain an understanding what motivates older individuals to switch to self-employment, profiles of necessity and opportunity entrepreneurs are developed in terms of personal and various other characteristics. 


\section{Grouping the Self-Employed}

A cluster analysis produces three groups of older self-employed workers. To label the three clusters, Table 1 shows the means of the clustering variables for each cluster, and a median value is reported in square brackets below the mean. In the first cluster, the "necessity" cluster ( $n=4,764)$, many selfemployed workers come from non-employment, and their taxable income and property remain small, while the situation in the second cluster, the "opportunity" cluster $(\mathrm{n}=859)$, is the reverse. For example, the median annual taxable income is only $€ 8,350$ in the necessity cluster, whereas it is $€ 100,200$ in the opportunity cluster.

Following the sociological theories of entrepreneurship (Clain, 2000), our interpretation is that individuals in the first (i.e., necessity) cluster were pushed into self-employment because of low income, while individuals in the second (i.e., opportunity) cluster were more likely to be pulled into it. These latter individuals had no compelling, financial reason to start a business. The third cluster $(n=3,080)$ includes older self-employed workers who are in between the two other clusters with regard to the three clustering variables. Thus, the clustering produces clear-cut results, although the second cluster remains small. This result does not necessarily mean that the number of opportunitydriven older self-employed workers is small because those in the third cluster, or at least some of them, may be classified as opportunity-driven entrepreneurs.

\section{Evaluating the Characteristics of Opportunity- and Necessity-Driven Self-Employed Workers}

To evaluate how various personal, family, and environmental factors vary among the self-employed workers belonging to each one of the clusters, their means in each cluster are first compared with 
each other. Table 1 shows the means of the variables in each cluster and the results based on a oneway analysis of variance (ANOVA) to test for significant differences between means.

The results based on ANOVA indicate that nearly all variables have significance. For example, the proportion of individuals who are male, married, and highly educated are substantially larger among the opportunity-driven self-employed than necessity-driven self-employed workers. The only insignificant variable is, surprisingly, the variable indicating whether the spouse is an entrepreneur. 
Table 1. The means of the variables for the three clusters

\begin{tabular}{lcccc}
\hline Variable & Cluster & $\begin{array}{c}\text { Significance of } \\
\text { the differences } \\
\text { (ANOVA) }\end{array}$ \\
\cline { 2 - 5 } & $\begin{array}{c}\text { 1. "Necessity" } \\
(\mathrm{n}=4,764)\end{array}$ & $\begin{array}{c}\text { 3. "Opportunity" "In-between" } \\
(\mathrm{n}=859)\end{array}$ & $\begin{array}{c}\mathrm{n}=3,080) \\
\text { (ANO) }\end{array}$ &
\end{tabular}

\section{Clustering variables}

Wageworker

Taxable income $(€ 1,000)$

Taxable property $(€ 100,000)$

\section{Independent variables}

Previous self-employment experience

Male

Level of education

- Basic (ref.)

- Intermediate

- High

Field of education

- Business and social sciences

- Technology

- Health and welfare

- Other (ref.)

Married or cohabiting

Spouse entrepreneur ${ }^{\mathrm{i}}$

Spouse non-employed ${ }^{\mathrm{i}}$

Spouse's taxable property ${ }^{\mathrm{i}}$

Urban municipality

Unemployment rate

0.38
$[0]$
8.80
$[8.35]$
0.26
$[0.07]$

0.80

[1]

166.8

[100.2]

2.97

[0.89]

\subsection{0}

0.57

0.40

0.34

0.26

0.14

0.22

0.05

0.59

0.75

0.17

0.37

0.38

0.60

0.12
0.51

0.83

0.15

0.13

0.72

0.27

0.30

0.15

0.28

0.87

0.15

0.26

0.98

0.80

0.10
0.73

[1]

36.7

[33.6]

0.49

[0.24]

\subsection{3}

0.68

0.27

0.27

0.47

0.21

0.28

0.08

0.44

0.82

0.16

0.31

0.44

0.69

0.11

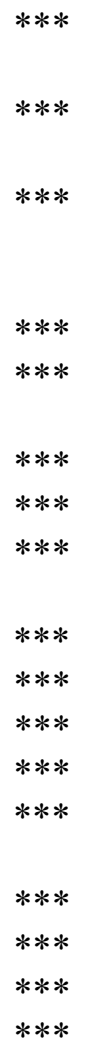

Note: * Significant at $10 \%$ level; $* *$ significant at $5 \%$ level; $* * *$ significant at $1 \%$ level. The medians of the clustering variables are given in squared brackets below the means. ${ }^{i}$ Mean values are computed only for married or cohabiting senior entrepreneurs. 
To analyse further the effect of each variable on the probability that a self-employed worker belongs to a specific cluster, a multinomial logit model is estimated. While in the previous analysis, the significance of independent variables was tested one at a time, now their mutual dependence will be taken into account in the model. In the estimation, the "necessity" cluster is designated as the reference category, which means that the probability of membership in the other two categories is compared to the probability of membership in the necessity category. Because the estimated coefficients of the model may be difficult to interpret, we also report the average marginal effects. They can be directly interpreted as average percentage changes in the probability of belonging to a particular cluster, which result from changes in the independent variables.

The estimation results from the multinomial logit model appear in Table 2. First, the results show that prior self-employment experience has significance. Previous self-employment experience is higher among necessity-driven self-employed workers than opportunity-driven self-employed workers. The ANOVA results above provide the same conclusion. Thus, in addition to having a large effect on the probability of entering self-employment at a later age (Tervo, 2014), previous self-employment experience also differentiates between those who have push or pull motivations.

Second, gender has great significance. The probability of being classified as an opportunity-driven self-employed worker is higher for men, while the probability of being classified as a necessitydriven self-employed is higher for women. Education is also a strong predictor. Those who are pushed into self-employment are less educated. The probability of being classified as an opportunity-driven self-employed or "in-between self-employed" is larger for individuals who have a high level of education. The field of education plays also a role. The estimated coefficients clearly show that those with a medical education are much more likely to be pulled into self-employment than those with another educational orientation. Furthermore, if a self-employed worker has a 
business (technical) education, her/his probability to be classified as a necessity-driven selfemployed worker is lower than (is similar to) the reference field of education.

Third, family characteristics also play certain role. Marriage has a positive effect on the probability of being classified as an opportunity-driven self-employed worker. On the contrary, if a selfemployed worker is unmarried, her/his probability of being pushed into self-employment increases. In addition, marriage differentiates the "in-between" category: those who were classified into this category were more likely to be married than unmarried. Having a non-employed spouse increases the probability of being pushed into self-employment, compared to the situation where spouse is in wage employment. On the contrary, whether a spouse is an entrepreneur or in wage employment does not differentiate the motives. An interesting finding is related to the spouse's taxable property: if the value of the spouse's property is high, the probability of being classified as an opportunitydriven self-employed worker increases.

Fourth, the results imply that regional environment is important. Necessity-driven self-employed workers are more likely to be from rural areas, and opportunity-driven (and "in-between") selfemployed workers are more likely to be from urban areas. Necessity-driven self-employment is also significantly more likely in areas with a high regional unemployment rate. Conversely, selfemployed workers are more likely to be classified as opportunity driven in regions with a low unemployment rate than in those with a high unemployment rate. 
Table 2. Multinomial logit model for the determinants of belonging to one of the clusters

\begin{tabular}{|c|c|c|c|c|c|}
\hline & $\begin{array}{l}\text { Cluster } 1 . \\
\text { "Necessity" }\end{array}$ & $\begin{array}{l}\text { Cluster } 2 . \\
\text { "Opportunity" }\end{array}$ & & $\begin{array}{l}\text { Cluster } 3 . \\
\text { In-between" }\end{array}$ & \\
\hline & Marginal effect & Coefficient & Marginal effect & Coefficient & Marginal effect \\
\hline Previous self-employment experience & $0.137 * * *$ & $-0.668 * * *$ & $-0.027 * * *$ & $-0.628 * * *$ & $-0.109 * * *$ \\
\hline Male & $-0.156^{* * *}$ & $1.610 * * *$ & $0.106^{* * *}$ & $0.532 * * *$ & $0.050 * * *$ \\
\hline \multicolumn{6}{|l|}{ Level of education } \\
\hline - Intermediate & -0.009 & -0.143 & -0.008 & 0.070 & 0.018 \\
\hline - High & $-0.189 * * *$ & $1.457 * * *$ & $0.095 * * *$ & $0.683 * * *$ & $0.094 * * *$ \\
\hline \multicolumn{6}{|l|}{ Field of education } \\
\hline - Business and social sciences & $-0.037 * *$ & $0.267^{*}$ & 0.015 & $0.146^{*}$ & 0.022 \\
\hline - Technology & -0.016 & 0.034 & -0.0005 & 0.081 & 0.016 \\
\hline - Health and welfare & $-0.171 * * *$ & $1.511 * * *$ & $0.129 * * *$ & $0.581 * * *$ & $0.043 *$ \\
\hline Married or cohabiting & $-0.062 * * *$ & $0.443 * * *$ & $0.025 * *$ & $0.256 * * *$ & $0.038 * *$ \\
\hline Spouse entrepreneur & -0.011 & 0.106 & 0.007 & 0.037 & 0.004 \\
\hline Spouse non-employed & $0.031 * *$ & $-0.208 * *$ & -0.011 & $-0.129 * *$ & -0.020 \\
\hline Spouse's taxable property & $-0.008 *$ & $0.078 * * *$ & $0.005^{* * *}$ & 0.030 & 0.003 \\
\hline Urban municipality & $-0.047 * * *$ & $0.492 * * *$ & $0.033 * * *$ & $0.161 * * *$ & 0.015 \\
\hline Unemployment rate & $1.050 * * *$ & $-7.208 * * *$ & $-0.392 * * *$ & $-4.380 * * *$ & $-0.658 * * *$ \\
\hline Constant & - & $-3.205 * * *$ & - & $-0.486^{* * *}$ & - \\
\hline
\end{tabular}

Number of observations $=8,703 ; \log$ likelihood $=-7285.1 ; \operatorname{LR} \operatorname{chi2}(26)=1548.1^{* * *} ;$ Pseudo $\mathrm{R}^{2}=0.096$

Note: * Significant at $10 \%$ level; ** significant at $5 \%$ level; $* * *$ significant at $1 \%$ level. 


\section{Summary of the Hypothesis Testing}

A summary of the findings and the confirmation of the hypotheses are shown in Table 3. Many, but not all, of the hypotheses are verified. Contrary to expectations, prior entrepreneurship experience does differentiate between diverse motivations of entrepreneurship (H1). Most seniors switching to entrepreneurship have previous experience in entrepreneurship, and previous experience relates to push and pull motivations: individuals with prior self-employment experience are more likely to be classified into necessity- than opportunity-driven self-employment. Men who enter selfemployment at older ages are more often opportunity driven than women are (H2a). Opportunitydriven self-employment at older ages increases with higher education $(\mathbf{H 2 b})$. The field of education also has some importance; individuals with medical (and business) education are pulled into selfemployment more than others (H2c). Family relations also play a role (H3a, H3b). Unmarried seniors are more likely than married seniors to have push motivations for self-employment. Contrary to expectations, having a spouse who is also an entrepreneur him-/herself does not differentiate seniors with pull and push motivations. Finally, living in an urban area enhances opportunity-driven entrepreneurship (H4a) and regional unemployment enhances necessity-driven entrepreneurship (H4b) at older ages. 
Table 3. Opportunity-driven self-employment at older ages: hypotheses and summary of findings

\begin{tabular}{|c|c|c|c|c|}
\hline Hypothesis & $\begin{array}{l}\text { Explanatory } \\
\text { Variables }\end{array}$ & $\begin{array}{l}\text { Expected } \\
\text { sign }\end{array}$ & Actual sign & $\begin{array}{l}\text { Probability of } \\
\text { opportunity- } \\
\text { driven self- } \\
\text { employment } \\
\text { increases }\end{array}$ \\
\hline 1. Prior activity & $\begin{array}{l}\text { Previous self-employment } \\
\text { experience }\end{array}$ & $+/-$ & - & No \\
\hline \multirow{3}{*}{$\begin{array}{l}\text { 2. Individual } \\
\text { characteristics }\end{array}$} & Male & + & + & Yes \\
\hline & Level of education & + & + & Yes \\
\hline & $\begin{array}{l}\text { Field of education: } \\
\text { business/technology/health }\end{array}$ & + & $+/ 0 /+$ & Partially \\
\hline \multirow{3}{*}{$\begin{array}{l}\text { 3. Family } \\
\text { relations }\end{array}$} & Married or cohabiting & + & + & Yes \\
\hline & Spouse entrepreneur & + & 0 & No \\
\hline & Spouse non-employed & - & - & No \\
\hline \multirow{2}{*}{$\begin{array}{l}\text { 4. Environmental } \\
\text { characteristics }\end{array}$} & Urban municipality & + & + & Yes \\
\hline & Regional unemployment & - & - & No \\
\hline
\end{tabular}

Note: “"” negative and significant coefficient; “+” positive and significant coefficient; "0” insignificant coefficient on "opportunity". 


\section{DISCUSSION AND CONCLUSION}

The results related to the question of whether older individuals who become self-employed are necessity driven or opportunity driven provide interesting insights that also carry implications for tailor-made policies. This study showed that individuals who were recognized to possess pull motives were more likely male and highly educated, often with a medical or business educational orientation, whereas those who were recognized to possess push motives were more likely female, unmarried, and less educated and less likely to have a medical or business educational orientation.

Detected gender differences add an interesting finding to the literature on female entrepreneurship. It is known that there are fewer female than male entrepreneurs in Finland and in many other countries. Earlier results have shown that differing behaviour accounts for differing rates of selfemployment between females and males in Finland (Tervo and Haapanen 2010). Tervo and Haapanen (2010) showed that non-monetary reasons are more important for women than men and concluded that females tend to choose self-employment if it is convenient in relation to their family and other situations. Our new result is that necessity-driven self-employment is more common among older women than among older men.

Several earlier studies for Finland have demonstrated that individuals' propensity to start their own business decreases with their level of education. Only for older workers has higher education been found to enhance entrepreneurship (Tervo 2014). In this study, we have shown that seniors with higher education are more likely to have been pulled into self-employment than seniors with less education. Furthermore, the field of education plays also a role. In particular, our results have clearly shown that those with a medical education are much more likely to be pulled into selfemployment than those with another orientation in education. Our analyses are based on comprehensive register data on the entire population, containing information on the level and field 
of education, but the data lack information on general entrepreneurial skills. Hence, further research is needed to consider to what extent formal education affects the entrepreneurial orientation after such factors have been controlled for.

Another interesting finding of this study was related to regional environment: living in an urban area increases the probability of being pulled into entrepreneurship, while living in a rural area increases the probability of being pushed into entrepreneurship. A comparable finding is obtained when the unemployment level of regions is analysed: regions with high unemployment push seniors into entrepreneurship, while regions with low unemployment pull them into it. Overall, these findings suggest that necessity-driven self-employment characterizes depressed regions, while opportunity-driven self-employment characterizes growth regions. Employment opportunities remain low in rural areas and in unemployment areas; for this reason, many older founders of new firms may start a business out of necessity, while in urban or low unemployment areas, they may more likely take advantage of a recognized opportunity.

A fourth remarkable finding was that necessity-driven self-employed workers are more likely to have prior self-employment experience. Thus, entrepreneurship is most likely habitual, especially for necessity-driven self-employed workers. For many seniors, entering self-employment is most likely a form of bridge employment. Of course, this fact could also contribute to extending careers. Further empirical research might address the extent to which these habitual, necessity-driven entrepreneurs are successful in their ventures. Dimensions of success that could be investigated include duration of self-employment and financial success. In terms of policy, an important question is also regarding what types of senior entrepreneurs succeed.

Although we have provided several valuable insights about selection into opportunity and necessity entrepreneurship, some causation must be considered when generalizing our findings to other 
contexts. The results may depend on the institutional country context and business cycle within a country. For example, our results are from a period of steady economic growth, between 2002 and 2006. However, during a recession, when the demand for labour is low, the push and pull motives for entering self-employment may be different. A novel feature of the current study was that the grouping of individuals into opportunity- and necessity-driven self-employed workers was based on a cluster analysis and financial register data. This approach has clear advantages, since the population registers are reliable and complete with no response or sample bias. Earlier research has been based on survey (GEM) data to investigate the motives of becoming self-employed. Further research is needed to investigate to what extent this difference in the measurement of motives can affect the findings.

Policymakers are keen to promote self-employment among older age groups as one way of offsetting higher unemployment and early retirement among these groups, thereby reducing demands on welfare that result from having an increased number of older people in the population (Curran and Blackburn 2001; Kyrö et al. 2012). Nonetheless, the opportunities of older people entrepreneurship are not fully understood, especially since the current policies seldom distinguish between unalike types of motives behind entrepreneurship. This study hopefully gives useful information on various motivations behind senior entrepreneurship.

\section{Acknowledgements}

This study is supported by the Strategic Research Council (SRC) at the Academy of Finland (project no. 303552). 


\section{References}

Bergman, Heiko, and Rolf Stenberg. 2007. "The changing face of entrepreneurship in Germany." Small Business Economics 28: 205-221.

Blanchflower, David G, and Andrew J Oswald. 1990. "Self-employment and the enterprise culture." In British Social Attitudes: the 1990 Report, edited by R. Jowell, S. Witherspoon and L. Brook. London: Gower.

Block, Jorn H., and Marcus Wagner. 2010. "Necessity and opportunity entrepreneurs in Germany: characteristics and earnings differentials." Schmalenbach Business Review 62: 154-174.

Bönte, Werner, Oliver Falck, and Stephan Heblich. 2007. "Demography and innovative entrepreneurship.”Jena: Jena Economic Research Papers \#2007 - 084.

Brünjes, Jürgen, and Javier Revilla Diez. 2013. “'Recession push' and 'prosperity pull' entrepreneurship in a rural developing context.” Entrepreneurship and Regional Development 25: $251-271$.

Clain, Suzanne Heller. 2000. "Gender differences in full-time self-employment." Journal of Economics and Business 52: 499-513.

Curran, James, and Robert A. Blackburn. 2001. "Older people and the enterprise society: age and self-employment propensities.” Work, Employment and Society 15: 889-902.

Davidsson, Per, Murray Low, and Mike Wright. 2001. "Editors' introduction: Low and MacMillan ten years on: achievements and future directions for entrepreneurship research." Entrepreneurship Theory and Practice 25: 5-15.

Dawson, Christopher, and Andrew Henley. 2012. “"Push” versus "pull” entrepreneurship: an ambiguous distinction?” International Journal of Behaviour \& Research 18: 697-719.

Dyer, W. Gibb, Jr. 1994. "Toward a theory of entrepreneurial careers.” Entrepreneurship Theory and Practice 19: 7-21. 
Earle, John S., and Zuzana Sakova. 2000. "Business start-ups or disguised unemployment? Evidence on the character of self-employment in transition countries." Labour Economics 7: 545-574.

Eijdenberg, Emiel L., and Enno Masurel. "Entrepreneurial motivation in a least developed country: push factors and pull factors among MSE's in Uganda." Journal of Enterprising Culture 21: 19-43.

Giacomin, Olivier, Frank Janssen, Jean-Luc Guyot, and Olivier Lohest. 2011. “Opportunity and/or necessity entrepreneurship? The impact of socio-economic characteristics of entrepreneurs." MPRA Paper no. 29506, Germany: University of Munich.

Gibb, Allan, and John Ritchie. 1982. "Understanding the process of starting small business." European Small Business Journal 1: 26-45.

Heimonen, Tomi. 2013. "Entrepreneurship in golden years - creative opportunity or not?" ChinaUSA Business Review 12: 52-66.

Heinonen, Jarna, Anne Kovalainen, Kaisu Paasio, Tommi Pukkinen, and Johanna Österberg. 2006. "From waged work to entrepreneurship - Study on routes from waged work to entrepreneurship in the social and health care sector and among business and technical university graduates (in Finnish).” Labour Research Publications 297, Ministry of Labour.

Johansson, Edvard. 2000. Essays on the determinants of self-employment. Publications of the Swedish School of Economics and Business Administration, Nr 85. Helsingfors.

Karoly, Lynn A., and Julie Zissimopoulos. 2004. "Self-employment and the 50+ population." Washington D.C. AARP Public Policy Institute.

Kautonen, Teemu, Erno T. Tornikoski, and Ewald Kibler. 2011. "Entrepreneurial intentions in the third age: the impact of perceived age norms." Small Business Economics 37: 219-234.

Kirkwood, Jodyanne. 2009. "Motivational factors in a push-pull theory of entrepreneurship." Gender in Management. An International Journal 24: 346-364. 
Kyrö, Paula, Aarni Moisala, Sari Nyrhinen, and Niko Levikari. 2012. "Towards flexible paths of senior entrepreneurship (in Finnish).” Aalto-University, School of Economics, Helsinki.

Le, Anh T. 1999. “Empirical studies of self-employment.” Journal of Economic Surveys 13: 381416.

Lévesque, Moren, and Maria Minniti. 2006. "The effect of aging on entrepreneurial behavior." Journal of Business Venturing 21: 177-194.

Leung, Danny, and Chris Robinson. 1998. "Explaining the recent rise in self-employment: lifecycle, cohort, and aggregate economy effects." University of Western Ontario mimeo.

Low, Murray B., and Ian C. MacMillan. 1988. "Entrepreneurship: past research and future challenges.” Journal of Management 35: 139-161.

Moore, Carol S., and Richard E. Mueller. 2002. "The transition from paid-employment to selfemployment in Canada: the importance of push factors.” Applied Economics 34: 791-801.

Niefert, Michaela. 2010. "Characteristics and determinants of start-ups from unemployment: evidence from German micro data.” Journal of Small Business \& Entrepreneurship 23: 409429.

Niittykangas, Hannu, and Hannu Tervo. 2005. "Spatial variations in intergenerational transmission of self-employment.” Regional Studies 39: 319-332.

Parker, Simon C. 2004. The Economics of Self-employment and Entrepreneurship. Cambridge: Cambridge University Press.

Parker, Simon C. 2009. The Economics of Entrepreneurship. Cambridge: Cambridge University Press.

Praag, C. Mirjam Van, and Hans Van Ophem. 1995. "Determinants of willingness and opportunity to start as an entrepreneur." Kyklos 48: 513-540.

Quinn, Joseph F. 2002. "Changing retirement trends and their impact on elderly entitlement programs." In Policies of an aging society, edited by Stuart H. Altman and David I. Schactman. Baltimore, MD: The John Hopkins University Press. 
Quinn, Joseph F., and Michael Kozy. 1996. "The role of bridge jobs in the retirement transition: gender, race and ethnicity.” The Gerontologist 36: 363-372.

Rees, Hedley, and Anup Shah. 1986. "An empirical analysis of self-employment in the UK." Journal of Applied Econometrics 1: 95-108.

Reynolds, Paul, David J. Storey, and Paul Westhead. 1994. "Cross-national comparisons of the variation in new firm formation rates." Regional Studies 28: 443-456.

Reynolds, Paul, S. Michael Camp, William D. Bygrave, Erkko Autio, and Michael Hay. 2002. GEM Global Entrepreneurship Report.

Ritsilä, Jari, and Hannu Tervo. 2002. "Effects of unemployment on new firm formation: micro-level panel data evidence from Finland." Small Business Economics 19: 31-40.

Robichaud, Yves, Rolland LeBrasseur, and K. V. Nagarajan. 2010. "Necessity and opportunitydriven entrepreneurs in Canada: an investigation into their characteristics and an appraisal of the role of gender." Journal of Applied Business and Economics 11: 59-79.

Ronstadt, Robert. 1984. Entrepreneurship: Text, Cases and Notes. Dover, M.A.: Lord.

Ruhm, Christopher J. 1990. "Bridge jobs and partial retirement." Journal of Labor Economics 8: $482-501$.

Tervo, Hannu. 2006. "Regional unemployment, self-employment and family background.” Applied Economics 38: 1055-1062.

Tervo, Hannu. 2007. "Self-employment transitions and alternation in Finnish rural and urban labour markets." Papers in Regional Science 87: 55-76.

Tervo, Hannu. 2014. "Starting a new business later in life." Journal of Small Business \& Entrepreneurship 27: 171-190.

Tervo, Hannu, and Mika Haapanen. 2010. "The nature of self-employment: how does gender matter?“ International Journal of Entrepreneurship and Small Business 9: 349-371.

Uusitalo, Roope. 2001. “Homo entreprenaurus?” Applied Economics 33: 1631-1638. 
Williams, Colin C. 2007. "Entrepreneurs operating in the informal economy: necessity or opportunity driven?” Journal of Small Business \& Entrepreneurship 20: 309-319.

Zhang, Ting. 2008. Elderly Entrepreneurship in an Aging US Economy: It's Never Too Late. Singapore: World Scientific. 